\title{
A COMPARATIVE STUDY OF THE EXCRETION OF WATER AND SOLIDS BY NORMAL AND ABNORMAL KIDNEYS
}

\author{
By F. H. LASHMET AND L. H. NEWBURGH \\ (From the Department of Internal Medicine, University of Michigan, Ann Arbor)
}

(Received for publication May 25, 1932)

A previous report by us (1) presented evidence to show that normal kidneys are able to excrete concentrated urine, while diseased kidneys are not. The manner in which this information was obtained was as follows: The subjects were on a constant diet for a preparation period of 3 days. Fluid intake was restricted to $1500 \mathrm{cc}$. daily. Beginning at 6:00 P.M. of the third day, all intake of food and fluid was stopped for 18 hours. Urine was collected at intervals during this fast and the specific gravity determined. It was found that normal kidneys were able to concentrate the urine to a specific gravity of 1.026 or above. Diseased kidneys were unable to reach 1.026 .

In order to observe these facts in more detail, further studies (2) have been made. This time a greater load was imposed upon the kidneys, but for a shorter period of time. The procedure was as follows: Beginning at 10:00 P.M., all intake of fluid and food, except a special diet, was withheld for 38 hours. Urine was collected at intervals during this period and the specific gravity determined.

In the previous study, the total available water was approximately $2800 \mathrm{cc}$. daily. In the latter one, the total available water was reduced to 700 cc. daily.

The solid intake of the body was practically the same in both studies.

Under these latter conditions, it was found that normal kidneys are able to concentrate the urine to a specific gravity of 1.029 or above. Diseased kidneys cannot reach 1.029. The more severe the renal damage is, the lower the concentrating ability of the kidneys was found to be.

The specific gravity of any solution is an expression of a ratio between water and solids in solution. As the kidneys become unable to concentrate the urine, the ratio of grams of water per gram of solid excreted must increase. Figure 1 illustrates this ratio of water to total solids in the urine at different specific gravities. This ratio holds for each specific gravity regardless of whether it is the maximal specific gravity attainable or that of a specimen obtained under submaximal conditions.

Since, in disease, there is an increase in the proportion of water per gram of solid excreted, it is important to determine what effect this high ratio has on the total 24 hour excretion of water and solids. 
The lower specific gravity in disease could be brought about in several ways. First, the total volume of urine excreted per unit of time might be normal, but the amount of solids contained therein be below the normal. In this case, there necessarily would be retention of excretory wastes. Second, the amount of solids excreted per unit of time might be normal but contained in an unusually large volume of urine. Under these circumstances, no retention of solids could exist. Third, there might be a combination of both the above possibilities, a decreased excretion of total solids in an increased volume of urine per unit of time.

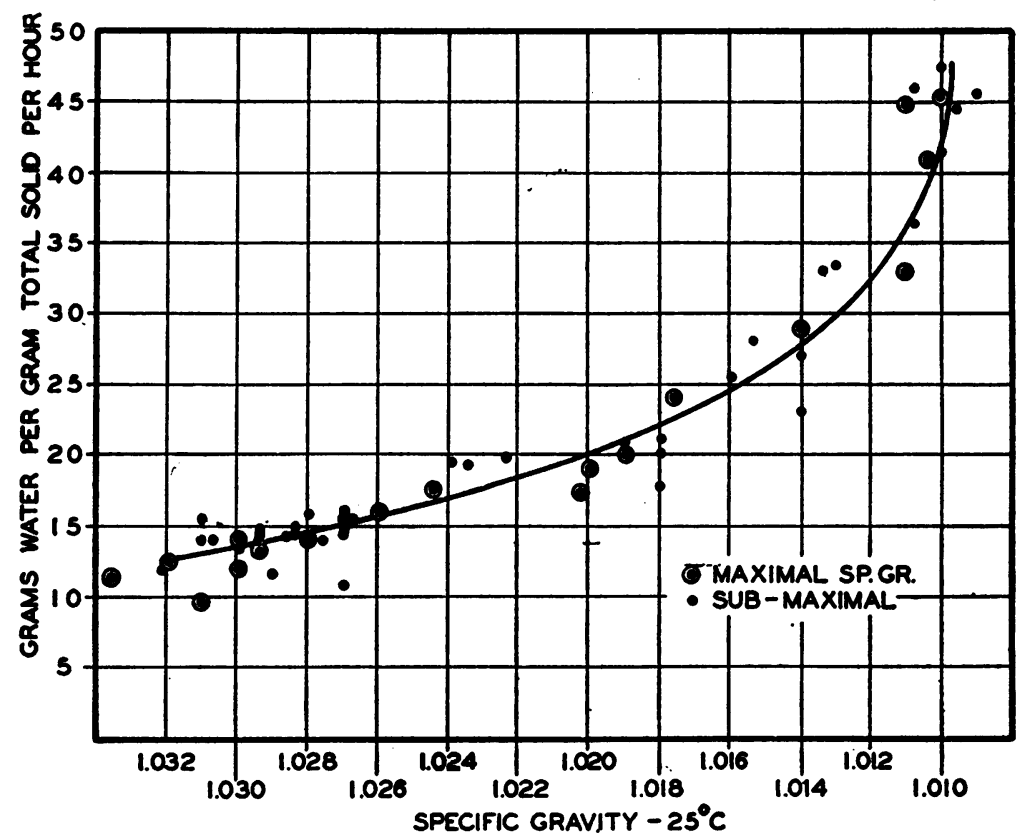

Fig. 1. Relationship of Water to Total Solids in the URine at Different Specific Gravities

These studies were done in order to determine what the conditions are in the case of diseased kidneys characterized by a low concentrating ability.

Both normal individuals and those with various types of renal disease were studied. The latter included cases of acute nephritis, chronic nephritis with edema, chronic nephritis with hypertension and no edema, essential hypertension with mild renal involvement, pyelonephritis, and tuberculosis of the kidneys.

The intake of solids was identical in every case. This consisted of a special diet containing protein 40 grams, fat 104 grams, carbohydrate 204 grams, and 1900 Calories. One gram of sodium chloride was added. 
Such a diet contains 6.536 grams of nitrogen, 9.1 grams of inorganic solids and 3.286 grams of chlorine. The menu of this diet is as follows:

\begin{tabular}{|c|c|c|}
\hline Food & Grams & Approximate Measure \\
\hline Corn flakes..... & 15 & $\frac{1}{2}$ cup \\
\hline$\ldots \ldots \ldots \ldots \ldots$ & 60 & 2 slices $-\frac{3}{8}$ inch \\
\hline Butter .................... & 20 & 2 squares, or 1 level tablespoon \\
\hline Cream, 40 per cent . ......... & 50 & $\frac{1}{1}$ cup \\
\hline 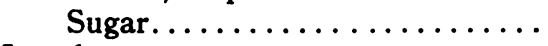 & 13 & 1 tablespoon \\
\hline unch: & & \\
\hline Beef steak. & 100 & $4 \times 4 \times \frac{1}{2}$ inch \\
\hline Potato (baked). & 80 & $1-2 \frac{1}{2}$ inch diameter \\
\hline Crackers $\ldots \ldots \ldots \ldots \ldots \ldots \ldots$ & 16 & \\
\hline$\ldots \ldots \ldots \ldots \ldots \ldots$ & 20 & 2 squares, or 1 level tablespoon \\
\hline$\ldots \ldots \ldots \ldots \ldots$ & 70 & 10 \\
\hline inner: & & \\
\hline Potato (baked)...... & . 80 & 1 as above \\
\hline Lettuce.................. & . 100 & $\frac{1}{4}$ head \\
\hline Crackers $\ldots \ldots \ldots \ldots \ldots \ldots \ldots$ & . 16 & \\
\hline$\ldots \ldots \ldots \ldots \ldots$ & . 20 & 2 squares, or 1 level tablespoon \\
\hline$\ldots \ldots \ldots \ldots \ldots \ldots$ & 30 & \\
\hline Peaches (canned) (no juice)... & 85 & 1 half \\
\hline & 75 & \\
\hline
\end{tabular}

The total water available when such a diet is fed is approximately 700 grams per 24 hours. This was calculated as follows: The water of the food was determined by desiccation. The average for 16 menus was 372 grams. The water of oxidation of the diet alone is 250 grams. However, this diet is submaintenance for many individuals, consequently body protein and fat must be oxidized. Thus the actual water of oxidation would be greater than that coming from the diet alone. A total water and energy exchange was obtained from 3 normal and 6 abnormal individuals in the series by the method described by Wiley and Newburgh (3). It was found that the amount of water available from all sources when such a diet is fed averaged 706 grams per 24 hours for this group.

Beginning at 10:00 P.M. the night before each experiment, all intake of fluid and food, except the special diet, was withheld for 34 hours. From 8:00 A.M. the following morning until 8:00 A.M. 24 hours later, all urine was collected as one specimen. During this 24 hour period, the special diet was taken.

Total solids and water of the urine were determined by the usual method of freezing and then desiccating over sulphuric acid. Specific gravity was determined at $25^{\circ} \mathrm{C}$. by the weight method, using weighing bottles of about 5 cc. capacity.

When the above conditions were imposed, two distinctly different responses were observed (Table I). These responses divided the subjects into two groups. The critical feature was the presence of that well- 
TABLE I

Effect of water restriction on the excretion of water and total solids by normal and diseased kidneys

\begin{tabular}{l|c|c|c}
\hline \hline Normal specific gravity & Case number & Urine water & Urine solids \\
\cline { 2 - 3 } 1.032 to 1.029 & & grams per 24 hours & grams per 24 hours \\
& 1 & 288 & 25.00 \\
2 & 354 & 25.26 \\
3 & 384 & 33.34 \\
4 & 432 & 37.23 \\
& 5 & 513 & 33.30 \\
& 6 & 550 & 39.32 \\
& 7 & 554 & 37.56 \\
& 8 & 574 & 32.95 \\
& Average & 456 & \\
\hline
\end{tabular}

Abnormal-Group A

\begin{tabular}{|c|c|c|c|}
\hline \multirow[t]{2}{*}{1.028 (incl.) to 1.025} & $\begin{array}{r}9 \\
10 \\
11 \\
12\end{array}$ & $\begin{array}{l}515 \\
550 \\
638 \\
675\end{array}$ & $\begin{array}{l}29.87^{*} \\
32.45^{*} \\
37.64^{*} \\
39.82^{*}\end{array}$ \\
\hline & Average & 594 & 34.94 \\
\hline \multirow[t]{2}{*}{1.024 (incl.) to 1.020} & $\begin{array}{l}13 \\
14 \\
15 \\
17 \\
18 \\
19 \\
20\end{array}$ & $\begin{array}{l}530 \\
650 \\
655 \\
672 \\
815 \\
825 \\
847\end{array}$ & $\begin{array}{l}25.44^{*} \\
35.75^{*} \\
32.91 \\
32.25^{*} \\
41.56^{*} \\
46.20^{*} \\
44.43\end{array}$ \\
\hline & Average & 713 & 41.22 \\
\hline \multirow[t]{2}{*}{1.019 (incl.) to 1.015} & $\begin{array}{l}21 \\
22 \\
23 \\
24 \\
25\end{array}$ & $\begin{array}{r}600 \\
770 \\
770 \\
1224 \\
1495\end{array}$ & $\begin{array}{l}25.80^{*} \\
31.57^{*} \\
36.98 \\
51.50^{*} \\
53.23\end{array}$ \\
\hline & Average & 971 & 39.81 \\
\hline \multirow[t]{2}{*}{1.014 (incl.) to 1.010} & $\begin{array}{l}27 \\
28 \\
29 \\
30\end{array}$ & $\begin{array}{l}1000 \\
1176 \\
1440 \\
1804\end{array}$ & $\begin{array}{l}29.00^{*} \\
25.67 \\
43.08 \\
33.00\end{array}$ \\
\hline & Average & 1355 & 32.68 \\
\hline \multicolumn{4}{|c|}{ Abnormal-Group B } \\
\hline $\begin{array}{l}1.0203 \\
1.0096\end{array}$ & $\begin{array}{l}26 \\
31\end{array}$ & $\begin{array}{l}247 \\
845\end{array}$ & $\begin{array}{l}13.82 \\
18.89\end{array}$ \\
\hline
\end{tabular}

* Calculated from specific gravity (2). 
known type of generalized edema that so characteristically appears as the first important sign of chronic, progressive kidney disease in young adults. The two groups are as follows:

A. Those subjects having renal damage without the nephrotic type of edema. (1) Chronic nephritics who never had edema, or in whom it had disappeared. Cases 9, 10, 11, 13, 15, 18, 20, 22, 23, 28, 29 and 30. (2) Essential hypertension with mild renal involvement. Cases 12 and 14. (3) Pyelonephritis. Cases 17, 19, 21 and 27. (4) Renal tuberculosis. Case 24. (5) Severe secondary anemia with mild renal damage and edema. Case 25.

B. Those subjects with chronic nephritis and the nephrotic type of edema. Cases 26, 31.

In Group A, the most striking deviation from the normal was the larger output of water. With each lowering of the specific gravity, a greater water excretion per gram of solid occurred. Inasmuch as a normal amount of solids was almost always excreted, the increased water output apparently compensated for the decreased ability of the kidneys to concentrate.

Since this group ingested the same amount of water as the normal group, but excreted more water, the extra urinary water must have been released from the body itself.

The subjects in Group B had edema of the nephrotic type. The concentrating ability of both of these subjects was below normal as was the case in Group A. In these patients, however, the response was different. The amount of water excreted was distinctly lower than that of Group A with corresponding specific gravities. In fact, the water excretion of Case 26 was even lower than that of the normal group. With the lowered water excretion, there was also a very low solid excretion.

In Group A, Cases 20 and 22 had the same type of nephritis as Cases 26 and 31 of Group B. However, the nephrotic edema which had been present in the former cases had disappeared before the experiment. Cases 20 and 22 responded to water deprivation by excreting a large amount of water, while Cases 26 and 31 did not. Other subjects in Group A (Cases 25 and 28) with edema which was not of the nephrotic type also excreted a large amount of water.

One might conclude that when nephrotic edema is present, the patients are less able to excrete water and solids. This would account for the presence of the edema and the lowered excretion of water and solids. But, as will be shown later, both Cases 26 and 31 could excrete water and solids. Hence, when nephrotic edema is present, the body water is more firmly held than in any of the other types studied, normal, "dry" nephritics of any type, cardiac edema and edema associated with severe anemia.

In order to compare the effects of "water restriction" with the administration of extra water, another study was made (Table II). Three nor- 
TABLE II

Comparison of the effect of restriction and administration of water on the excretion of water and total solids by normal and diseased kidneys

\begin{tabular}{|c|c|c|c|c|c|}
\hline \multirow{2}{*}{$\begin{array}{l}\text { Case } \\
\text { num- } \\
\text { ber }\end{array}$} & \multirow{2}{*}{ Diagnosis } & \multicolumn{2}{|c|}{$\begin{array}{c}\text { Part A, } \\
\text { water } \\
\text { restricted }\end{array}$} & \multicolumn{2}{|c|}{$\begin{array}{c}\text { Part B. } \\
\text { water } \\
\text { as desired }\end{array}$} \\
\hline & & $\begin{array}{c}\text { Urine } \\
\text { water }\end{array}$ & $\begin{array}{l}\text { Urine } \\
\text { solids }\end{array}$ & $\begin{array}{l}\text { Urine } \\
\text { water }\end{array}$ & $\begin{array}{l}\text { Urine } \\
\text { solids }\end{array}$ \\
\hline \multirow{5}{*}{$\begin{array}{r}5 \\
16 \\
8\end{array}$} & \multirow{5}{*}{ 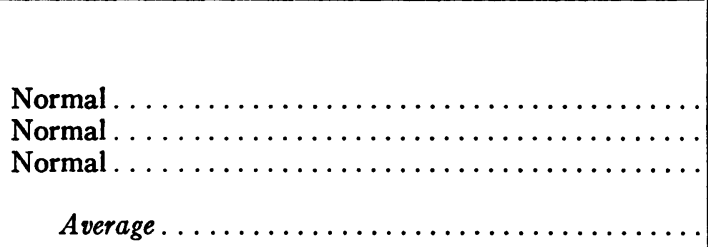 } & \begin{tabular}{|c|} 
grams \\
per \\
hour
\end{tabular} & $\begin{array}{c}\text { grams } \\
\text { per } \\
\text { hour }\end{array} \mid$ & $\begin{array}{c}\text { grams } \\
\text { per } \\
\text { hour }\end{array}$ & $\begin{array}{l}\text { grams } \\
\text { per } \\
\text { hour }\end{array}$ \\
\hline & & 17.90 & 1.266 & 21.36 & 1.551 \\
\hline & & 20.74 & 1.505 & 27.79 & 1.428 \\
\hline & & 23.93 & 1.565 & 60.50 & 1.655 \\
\hline & & 20.86 & 1.445 & & 1.545 \\
\hline \multirow{2}{*}{$\begin{array}{l}30 \\
28\end{array}$} & Chronic nephritis with hypertension, no edema & 75.16 & 1.375 & 205.10 & 1.572 \\
\hline & $\begin{array}{l}\text { Chronic nephritis with hypertension, cardiac failure, } \\
\text { edema present } \ldots \ldots \ldots \ldots \ldots \ldots \ldots \ldots \ldots \ldots \ldots \ldots\end{array}$ & 48.99 & 1.069 & & 1.148 \\
\hline 31 & Chronic parenchymatous nephritis, edema moderate. & 35.20 & 0.787 & 67.62 & 1.249 \\
\hline 26 & Chronic parenchymatous nephritis, edema marked... & 8.78 & 0.505 & 164.50 & 1.445 \\
\hline 25 & Anemia -secondary, severe edema moderate.. & 55.07 & 1.676 & 62.28 & 2.218 \\
\hline
\end{tabular}

mal and 6 abnormal subjects of the above series were studied. The latter were selected because of the various types of renal disease which they represented.

The same conditions were maintained as previously described except that as shown in part B (Table II), extra water was allowed as desired.

When the normal group were allowed extra water, the average solid excretion was 1.545 gram per hour. This was not strikingly greater than when the available water was small.

When the abnormal group were allowed extra water there was a striking increase in the water excreted. With the increased water excretion, there was also a marked increase in the solid excretion. This response was the same in the various types of disease, whether edema was present or absent and whether the edema was of the nephrotic type or otherwise. It should be especially noted that Cases 26 and 31 increased the water excretion remarkably and with it a solid excretion approaching the normal.

Case 26 presents striking evidence in support of the view that retention of solids is to be attributed solely to an insufficient intake of water. Since the low concentrating ability necessitates an increased volume of urine to remove the urinary wastes, and since body water is not easily given up in nephrotic edema, the only chance of preventing retention of urinary solids is by the ingestion of a really large amount of water. 


\section{SUMMARY}

Individuals with renal damage are unable to form as concentrated urine as normal. This necessarily means that the urine in the former has a high water/total solid ratio. It naturally follows that if the individual is to excrete the normal amount of solid waste products per 24 hours, he can accomplish this only by means of a large volume of urine. The lower the concentrating ability of the kidneys, the greater must the volume of urine be if no retention is to occur.

When water is restricted there are two distinctly different responses by individuals with renal disease. In the first group are those individuals having renal disease unaccompanied by the nephrotic type of edema. This group has a large volume of urine per 24 hours in spite of the small intake of water. This extra urine water is released from the body itself. In the second group are those individuals having renal disease accompanied by the nephrotic type of edema. This group has a small volume of urine per 24 hours. This is not due to the inability of the kidneys to excrete water. It is due to the unusually great affinity of the tissues for water.

When water is freely allowed, there is no difference in the response of the two types. Increased water ingestion is followed by both an increased water excretion and solid elimination. This response is the same whether edema is present or absent and whether this edema is of the nephrotic type or otherwise.

Apparently the process of excretion of waste products in renal disease is fundamentally one which avoids the retention of solids by increasing the water output as a compensation for a low concentrating ability. If the amount of ingested water is too small for this purpose, body water may be released. If the body water is not released, then the process fails and retention of wastes results. In either case, an extra large amount of ingested water is needed to insure the complete removal of solid wastes.

\section{BIBLIOGRAPHY}

1. Lashmet, F. H., and Newburgh, L. H., J. Am. Med. Assoc., 1930, xciv, 1883. The Specific Gravity of the Urine as a Test of Kidney Function.

2. Manuscript submitted for publication.

3. Wiley, F. H., and Newburgh, L. H., J. Clin. Invest., 1931, x, 723. An Improved Method for the Determination of Water Balance. 